\title{
Accumulation of heavy metals in the soil due to annual dressings with sewage sludge
}

\author{
O. J. Hemkes, A. Kemp and L. W. van Broekhoven \\ Centre for Agrobiological Research (CABO), Wageningen, the Netherlands
}

Accepted: 3 September 1980

Key words: heavy metals, sewage sludge, soil, leaching

\section{Summary}

In a long-term fertilizing experiment on permanent grassland, dressings of sewage sludge were applied at different rates. In 5 successive years $0,6,12$ and 18 tonnes of sludge per hectare per year were applied on a dry matter basis. The accumulation of a number of heavy metals in the soil was measured to obtain a better understanding of the relation plant-soil. To gain some idea of the translocation of heavy metals to deeper layers, the soil was sampled to depths of $55 \mathrm{~cm}$. The contents of $\mathrm{Cd}, \mathrm{Cu}$ and Mo had distinctly increased into the $15-25 \mathrm{~cm}$ layer. Some heavy metals showed a slight increase in the $45-55 \mathrm{~cm}$ layer, but only at the highest sludge level.

\section{Introduction}

To limit as much as possible the pollution of surface waters various countries have paid much attention to the treatment of sewage. The number of sewage treatment plants is still growing and consequently the amount of sewage sludge. In the Netherlands 86500 tonnes of sludge, on a dry matter basis, was produced in 1970. This had grown to 137000 tonnes in 1974 (Brouwer, 1977) and to about 200000 tonnes in 1978 (van Engers, 1980).

Sewage sludge, besides being a valuable fertilizer, is a good product for soil improvement, because of its high content of organic material (de Haan, 1976). It is therefore not surprising that the sewage treatment boards try to find markets for this sludge in agriculture and horticulture. However, transport costs limit its use to the direct neighbourhood of the treatment plants.

According to the most recent data (van Engers, 1980), in 1978 about half of the sludge produced, on a dry matter basis, was profitably used, for example in agriculture and horticulture, in public gardens and for the raising of areas. The remaining half was dumped.

The usefulness of sewage sludge is determined by its origin. Normally, sludge of purely domestic origin can be used without drawbacks, although even then only restricted use - as in the Netherlands - would be advisable. The contents of heavy metals in the sludge of industrial origin may be so high that use in agriculture and horticulture is not advisable. When used as a dressing or as a soil improver, the 
crops grown on this sludge may show such high contents of heavy metals that consumption of these products may be hazardous to the health of man and animals.

Although sewage sludge is also used on grassland, little is known about the uptake of heavy metals by grassland plants and about the effect a nitrogen fertilizer application might have on this. Only few data are available on the translocation of the different heavy metals to lower soil layers.

This paper will only deal with the effect of annual dressings of sewage sludge on the contents of a number of heavy metals at various depths in the soil. In a subsequent paper a detailed study will be made of the uptake of a number of heavy metals by grassland plants.

\section{Experimental design}

In 1973, a long-term field experiment was layed out in permanent grassland on sandly soil (ca. $5 \%$ organic matter, $\mathrm{pH}-\mathrm{KCl} 5.9$ in the layer $0-5 \mathrm{~cm}$ ) on the experimental farm 'Droevendaal' at Wageningen. Each February, four different sewage-sludge dressings were applied, viz $0,6,12$ and 18 tonnes/ha on a dry matter basis. In the tables and frequently also in the text the sludge treatments are indicated with S0, S1, $\mathrm{S} 2$ and S3, respectively.

Soil samples were taken every year before the sludge dressings. Initially, sampling was limited to the layers $0-5$ and $5-15 \mathrm{~cm}$. In view of the soil intake of grazing animals, the content of heavy metals in the top soil layer is important. From 1975 onwards the layer $0-5 \mathrm{~cm}$ was therefore divided into the layers $0-2.5$ and $2.5-5 \mathrm{~cm}$.

In Table 2 the contents for 1974 in the layers $0-2.5$ and $2.5-5 \mathrm{~cm}$ have been estimated on the basis of these contents in the same layers in more recent years.

When based on the analyses higher contents were to be expected in deeper soil layers, these layers were included in the next sampling. Ultimately, the soil was sampled to a depth of $55 \mathrm{~cm}$.

In the first two years only the contents of cadmium, lead, zinc and copper were determined in the soil samples and in the sewage sludge samples. From 1975 onwards the contents of nickel, chromium, cobalt, molybdenum, manganese and iron were included in the analyses.

\section{Methods of analysis}

After drying at $105^{\circ} \mathrm{C}$ the sludge and soil samples were pulverized with a hammer mill with a 1-mm sieve. Except for molybdenum all the metals were analysed by atomic absorption (AAS). The Mo content was determined by a colorimetric method (Perrin, 1946) after destruction with nitric acid and sulphuric acid. The lower limit of this determination is $0.3 \mathrm{mg}$ Mo per $\mathrm{kg}$, proceeding from $3 \mathrm{~g}$ of sample.

In determining the other metals by AAS an extraction with nitric acid was used. The glassware was rinsed beforehand with nitric acid ( $4 \mathrm{~mol} / \mathrm{litre})$. The acids used $\left(\mathrm{HNO}_{3}\right.$ and $\mathrm{HCl}$ ) were obtained from Merck (Suprapur). The salts required for the calibration curves were from BDH (AR). Double-demineralized water was used and in each series of determinations a blank was included. Of the samples $\mathbf{3} \mathrm{g}$ were 
weighed in a volumetric flask of $100 \mathrm{ml}$, adding $25 \mathrm{ml}$ of $7 \mathrm{~mol} /$ litre $\mathrm{HNO}_{3}$. The mixture was left overnight and then heated and kept at $130{ }^{\circ} \mathrm{C}$ for four hours. After cooling, the solution was made up with water to $100 \mathrm{ml}$. The solution was filtered through an ash-free filter and $50 \mathrm{ml}$ of the filtrate were transferred to a $100-\mathrm{ml}$ beaker. This liquid was evaporated to dryness over a heating plate and the residue was treated twice with $2 \mathrm{ml}$ of concentrated nitric acid and after this twice with $2 \mathrm{ml}$ of concentrated hydrochloric acid. After each treatment the liquid was evaporated to dryness at $135^{\circ} \mathrm{C}$.

The residue was solved in $20 \mathrm{ml}$ of $1 \mathrm{~mol} /$ litre $\mathrm{HCl}$ after which the solution was centrifuged and next analysed by atomic absorption. If necessary, the liquid was diluted to a concentration suitable for measurement. All these solutions were measured by a Varian AA-4 or a Varian AA-6 spectrophotometer. The AA-6 was equipped with a simultane background correction, with the AA-4 the background correction was carried out separately with a $\mathrm{H}_{2}$ lamp.

A mixture of acetylene and air was used as a calibration flame. The flame (height, temperature and such) was adjusted to the various metals in such a way that no inter-element interference could occur.

Experiments with additions of possibly interfering metals to calibration lines did not show deviations.

In general the values measured were far above the determination limit under the prevailing conditions. The values below this limit have been indicated as smaller than $(<)$ this limit value. When interpreting the values, it should be realized that those near the determination limit are less accurate than the higher values. The hammer mill almost certainly contributed to contamination of the soil samples. Measurements have shown that especially iron will cause some contamination due to pulverization. Determinations of the organic matter fraction (wet method) and the $\mathrm{pH}$ value of the soil were carried out according to standard specifications (Hofstee \& Fien, 1971).

\section{Results and discussion}

The chemical composition of the sewage sludge used in the years 1973-1977 is shown in Table 1. The sludge used in 1973 and 1974 came from the same sewage treatment plant. In 1975 sludge of another plant was obtained for a number of succeeding years, therefore the contents of the various heavy metals in this sludge varied only slightly during the following experimental years.

Striking is that the $\mathrm{Pb}$ content in the sludge of the second plant was 3 to 5 times higher than that in the sludge used in the first two experimental years. The contents of cadmium, zinc and copper were at the same level in both sludge types.

Table 1 also gives the average composition of sewage sludge of domestic origin according to de Haan (1976). The contents of heavy metals in this sludge are distinctly lower than in the sludge used in this experiment. The Cd content, for example, was a factor 40 lower in the domestic sludge than the average $\mathrm{Cd}$ content in the sludge used in the field experiment. Table 2 shows the effect of the various sludge applications in 5 succeeding years, on the contents of heavy metals at various depths in the 
Table 1. Chemical composition of sewage sludge of different origins.

\begin{tabular}{|c|c|c|c|c|c|c|}
\hline & \multicolumn{5}{|c|}{ Domestic + industrial (this trial) } & \multirow{2}{*}{$\begin{array}{l}\text { Domestic } \\
\text { (de Haan, 1976) }\end{array}$} \\
\hline & 1973 & 1974 & 1975 & 1976 & 1977 & \\
\hline Dry matter $(\mathrm{g} / \mathrm{kg})$ & 300 & & 252 & 245 & 262 & \\
\hline Organic matter (g/kg DM) & 468 & 395 & 448 & 503 & 467 & 480 \\
\hline Nitrogen $(\mathrm{g} / \mathrm{kg} \mathrm{DM})$ & 22.5 & 17.7 & 24.1 & 24.4 & 23.4 & 30.8 \\
\hline Ca (g/kg DM) & & & & & 40.7 & 33.0 \\
\hline $\mathrm{pH}-\mathrm{KCl}$ & 5.5 & 6.9 & 6.5 & 6.6 & 6.8 & \\
\hline \multicolumn{7}{|l|}{ Metals $(\mathrm{mg} / \mathrm{kg})$} \\
\hline $\mathrm{Cd}$ & 370 & 215 & 316 & 349 & 327 & 8 \\
\hline $\mathrm{Pb}$ & 450 & 333 & 1561 & 1693 & 1616 & 250 \\
\hline $\mathrm{Zn}$ & 4941 & 3149 & 3953 & 4353 & 4055 & 1650 \\
\hline $\mathrm{Cu}$ & 1446 & 722 & 1594 & 1724 & 1661 & 420 \\
\hline $\mathrm{Ni}$ & & & 497 & 573 & 630 & 30 \\
\hline $\mathrm{Cr}$ & & & 2274 & 2487 & 2086 & 130 \\
\hline Co & & & 62 & 80 & 91 & \\
\hline Mo & & & 144 & 168 & 117 & \\
\hline $\mathrm{Mn}$ & & & 1071 & 1186 & 1151 & 830 \\
\hline $\mathrm{Fe}$ & & & 36500 & 42200 & 43100 & 28700 \\
\hline
\end{tabular}

soil. Of course, the contents in the top $2.5 \mathrm{~cm}$ have increased more considerably than in the deeper layers. This is important, because with animals grazing under adverse conditions upwards $10 \%$ of the dry matter intake may consist of soil (Field \& Purvis, 1964).

The increase in the contents of the different heavy metals in the topsoil layer is primarily dependent on the contents in the sludge in proportion to the initial contents in the soil. The mobility of the metal ion is also important, because this will determine the rate of penetration to the subsoil. A possible decrease in the contents in the topsoil is closely related to this. The SO values mentioned in Table 2 are averages of the experimental years. To a depth of $15 \mathrm{~cm}$ this is an average of the initial situation in 1973 and of the S0 values found during the subsequent years. Because deeper layers were included in soil sampling during the experiment, the S0 values of these layers are based on fewer observations.

Table 2 shows that under the influence of the various sludge applications the $\mathrm{Cd}$ content in the soil increased considerably. In the $0-2.5 \mathrm{~cm}$ layer this value is already 7 times higher after one sludge dressing at a rate of 6 tonnes of dry matter per hectare per year. After 5 annual applications at the same rate the $\mathrm{Cd}$ content in this layer increased from 0.7 to upwards $15 \mathrm{mg}$ per $\mathrm{kg}$ of dry soil. This is roughly 20 times the initial value. When the soil intake by grazing cattle is $5 \%$ of the total dry matter intake, the $\mathrm{Cd}$ content in the ration would be some $0.3 \mathrm{mg}$ per $\mathrm{kg}$ of dry matter higher after applying 6 tonnes of such sludge, only once. After 5 annual dressings at a rate of 6 tonnes of dry sludge this increase would be about $0.8 \mathrm{mg}$ per $\mathrm{kg}$ of dry matter. The sludge dressings at rates of 12 and 18 tonnes of dry matter per year (in the table 


\begin{tabular}{|c|c|c|c|c|c|c|}
\hline & $\stackrel{\infty}{\vdots}$ & 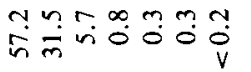 & 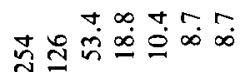 & 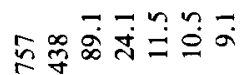 & 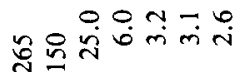 & 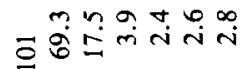 \\
\hline & $\underline{a}$ & 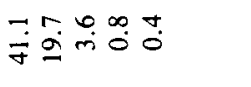 & 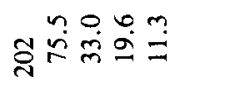 & 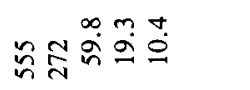 & মa & \\
\hline n & $\stackrel{2}{2}$ & 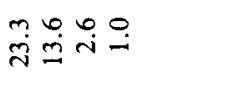 & 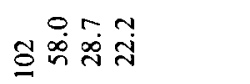 & 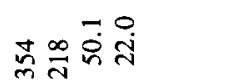 & 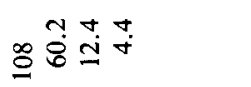 & \\
\hline & $\frac{n}{2}$ & $\vec{n}_{\infty}^{+} \underset{\infty}{+}$ & 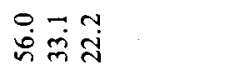 & 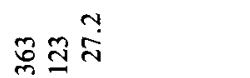 & 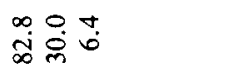 & \\
\hline & 蒿 & $\ddot{m} \dddot{0} \underset{0}{0}$ & nृ? & 융율 & 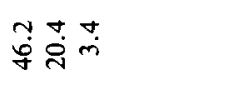 & \\
\hline & $\stackrel{\infty}{\stackrel{\infty}{\Omega}}$ & 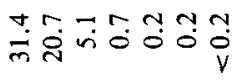 & 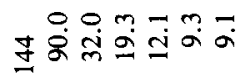 & 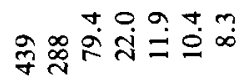 & 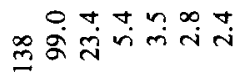 & 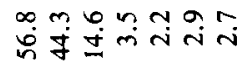 \\
\hline & s. & 苛足 & 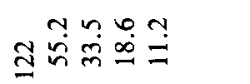 & లై & 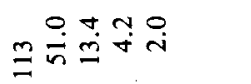 & \\
\hline กู & 号 & 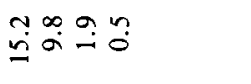 & 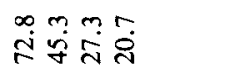 & 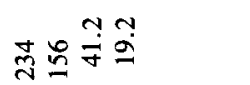 & 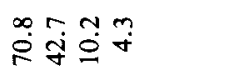 & \\
\hline & $\stackrel{n}{2}$ & $\ddot{m} \ddot{m} \stackrel{\infty}{0}$ & 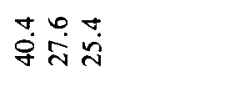 & 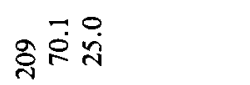 & 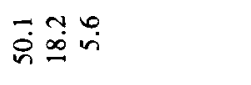 & \\
\hline & 去 & $\stackrel{\infty}{\infty}=\dot{\forall}$ & 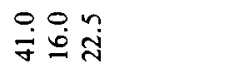 & $\Xi \stackrel{\circ}{\nabla} \stackrel{0}{9}$ & î̀ & \\
\hline & $\stackrel{\infty}{5}$ & 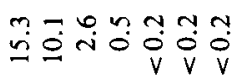 & 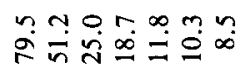 & 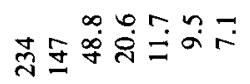 & 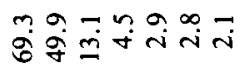 & 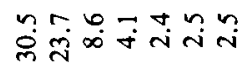 \\
\hline & 5 & తి & $\begin{array}{l}\sim \\
\\
\end{array}$ & 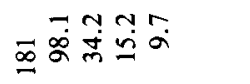 & 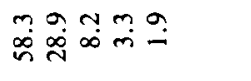 & \\
\hline $\bar{n}$ & $\stackrel{0}{2}$ & 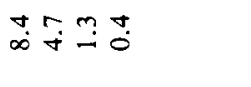 & $\begin{array}{l}\dot{\sim} \\
\dot{n} \dot{m} \dot{\sim}\end{array}$ & m잉요 & 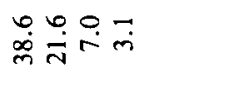 & \\
\hline & $\frac{n}{a}$ & $m \underset{r}{m} \stackrel{\infty}{i}$ & 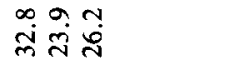 & $\stackrel{\infty}{=} \overrightarrow{\dot{d}}$ & 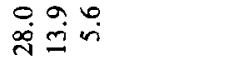 & \\
\hline & $\frac{⿱}{5}$ & ज忘 & 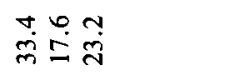 & 家守易 & $\vec{\Xi} \dot{0} \vec{m}$ & \\
\hline 8 & & 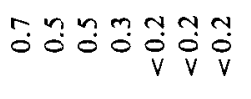 & 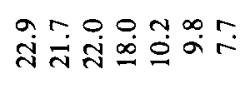 & 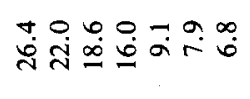 & 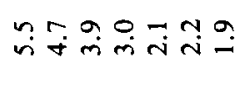 & 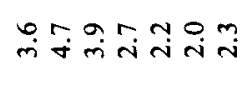 \\
\hline 离 & & 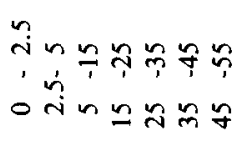 & 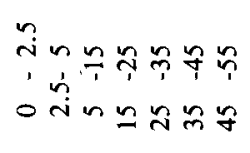 & 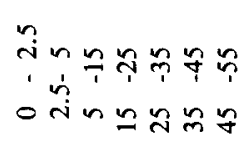 & 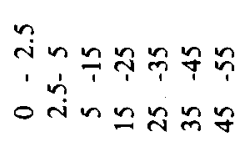 & 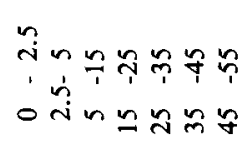 \\
\hline एँ & & $\bar{\mho} \stackrel{\widehat{\vartheta}}{\varrho}$ & 울 & sี & $\exists \stackrel{0}{=}$ & $z \stackrel{\widehat{Q}}{\mathbf{d}}$ \\
\hline
\end{tabular}


SEWAGE SLUDGE DRESSINGS AND HEAVY METALS IN SOIL

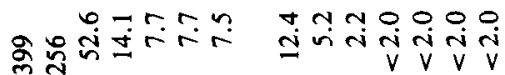

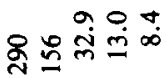

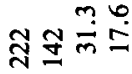

$\stackrel{\sim}{\sim} \stackrel{\infty}{\infty}$

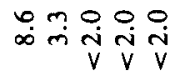

in유융

$\mathrm{V} V \mathrm{~V}$

$v V V$
운용

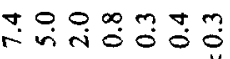

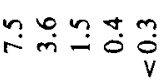

ํำ

$\ddot{\circ} \stackrel{m}{0} \dot{0}$

iisio

$\mathrm{V} V \mathrm{~V}$

운요 $\stackrel{i}{v}$

$\vee \vee \vee$

药守

anOm no mnOOOOO

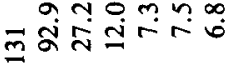

r.

อิที่⿺辶่

官苍完芒

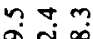

$\sin \infty$

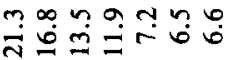

in

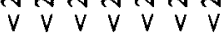

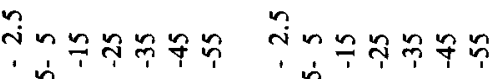

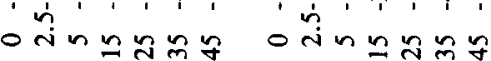

Uั $8 \stackrel{0}{0}$

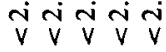

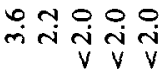

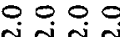

$\mathrm{V} V \mathrm{~V} V$

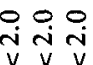

$R \vee v$

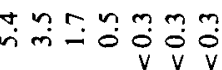

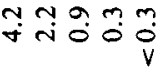

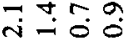

紊守苛

$\approx \infty ⿻ 0$

$\stackrel{\sim}{N} \stackrel{\infty}{=}$

t?

유ㅇㅗㅡ

i

mथّ

mơ

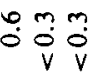

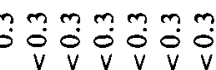

ตํํำำㅇํㅇ

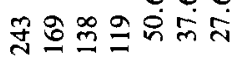

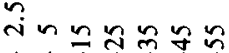

in่

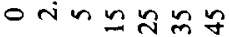

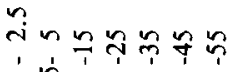

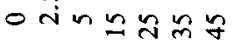

总告星它

오ㅇㅝㅡㄴ

유용

$n+\infty$

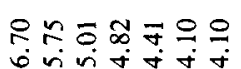

छே

安安安

กุกิ

$\forall \dot{\forall} \dot{0}$

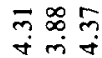

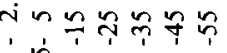

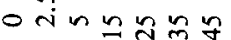

요

요 $\infty$

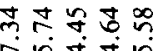

ติกั่

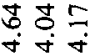


S2 and S3, respectively) will increase the Cd contents in the $0-2.5 \mathrm{~cm}$ layer to 31.4 and $57.2 \mathrm{mg}$ per $\mathrm{kg}$ of soil by the end of the experiment. At the lowest sludge dressing cadmium penetrated to a depth of $25 \mathrm{~cm}$ in the soil profile. In the other two sludge treatments the penetration of cadmium was somewhat deeper, although this was hardly demonstrable.

The $\mathrm{Pb}$ contents in the $0-2.5 \mathrm{~cm}$ layer showed a relatively smaller increase than that of cadmium. The supply of $\mathrm{Cd}$ with the sludge was the highest with respect to its content in the soil. After the fifth sludge dressing in 1977, the Pb contents in the treatments S1, S2 and S3 roughly were 80,140 and $250 \mathrm{mg} \mathrm{kg}$ of soil. This is $3.5,6$ and 11 times the initial content in the soil, respectively. During the experimental period the lead did not penetrate deeper into the soil profile than $20-25 \mathrm{~cm}$, neither at the highest sludge dressings.

The $\mathrm{Zn}$ contents in the top $2.5 \mathrm{~cm}$ of soil, after one dressing of sludge at the three rates, increased from 26.4 to $91.9,141$ and $230 \mathrm{mg}$ per $\mathrm{kg}$ of dry soil, respectively. By the end of the experiment the $\mathrm{Zn}$ contents in the same soil layer had increased to 234,439 and $757 \mathrm{mg}$ per $\mathrm{kg}$ of soil. The table shows that a distinct effect of the three sewage sludge dressings could be observed on the $\mathrm{Zn}$ content in the $15-25 \mathrm{~cm}$ layer. Although there is a slight difference between the 0 treatment and the three sludge levels in deeper layers, the difference in the effect between these sludge dressings is less distinct.

After one year the $\mathrm{Cu}$ content at the lowest sludge dressing in the $0-2.5 \mathrm{~cm}$ layer was more than 3 times the initial content to almost $20 \mathrm{mg}$ per $\mathrm{kg}$ of soil. After 5 years the content in the top $2.5 \mathrm{~cm}$ of soil of the same treatment had increased to almost $70 \mathrm{mg}$ per $\mathrm{kg}$ of soil. In the treatments S2 and S3 in the same period the $\mathrm{Cu}$ contents in the same layer increased to 138 and $265 \mathrm{mg}$ per $\mathrm{kg}$ of dry soil. In the $2.5-5 \mathrm{~cm}$ layer the $\mathrm{Cu}$ contents in the treatments $\mathrm{S} 1, \mathrm{~S} 2$ and $\mathrm{S} 3$ had increased to approximately 50,100 and $150 \mathrm{mg}$ per $\mathrm{kg}$ of soil, respectively. In the $0-5 \mathrm{~cm}$ layer, normally sampled in grassland, the $\mathrm{Cu}$ contents at the different sludge levels had increased to almost 60,120 and $200 \mathrm{mg}$ per kg of soil. Up to a depth of $25 \mathrm{~cm}$ the $\mathrm{Cu}$ contents increased distinctly. This applies to all the sludge treatments. In the deeper layers the difference between sludge dressings or no sludge is still observable, but the difference between the rates applied is only slight.

The contents of chromium, cobalt, molybdenum, manganese and iron were not determined in the years 1973 and 1974 . The content of nickel could only be assessed reliably in 1978.

After 5 years the $\mathrm{Ni}$ contents in the $0-2.5 \mathrm{~cm}$ layer were in the sludge treatments $\mathrm{S} 1, \mathrm{~S} 2$ and S3 30.5, 56.8 and $101 \mathrm{mg}$ per $\mathrm{kg}$ of dry soil, respectively. This is almost $8.5,16$ and 28 times the initial content which was $3.6 \mathrm{mg} \mathrm{Ni}$ per $\mathrm{kg}$ of soil. Table 2 shows that sludge application increased the Ni contents down to the $15-25 \mathrm{~cm}$ layer. A distinct difference between the various sludge treatments with respect to the $\mathrm{Ni}$ content does not extend beyond the $5-15 \mathrm{~cm}$ layer.

A distinct increase in the $\mathrm{Cr}$ contents due to the different sewage sludge treatments can be seen down to the $15-25 \mathrm{~cm}$ layer. Although even at greater depth there seems to be a slight effect of the sludge dressings on the $\mathrm{Cr}$ content, the differences between the sludge levels are not distinct. The effect of the sludge dressings on the 
Co content is only observable in the top $5 \mathrm{~cm}$ layer of the soil.

The effect of the different sludge dressings on the Mo content still shows variation down to a depth of approximately $25 \mathrm{~cm}$. Only the highest sewage sludge rate seems to have a demonstrable effect on the Mo content at greater depth. However, this is not beyond $45 \mathrm{~cm}$.

With respect to the heavy metals previously discussed, the contents of manganese and iron in the $0-2.5 \mathrm{~cm}$ layer only show a slight rise due to the sludge dressings. This is not surprising, because the differences between the contents of these metals in the sludge used and those in the soil are much smaller than for the other metals discussed in this paper. Due to the sewage sludge dressings the $\mathrm{pH}$ value in the top 5 $\mathrm{cm}$ layer of the soil increased to 7 and even somewhat higher, depending on the rate of the dressing. In the $\mathrm{S} 1$ treatment the contents of cadmium, zinc and copper in the $0-5 \mathrm{~cm}$ layer already attained such high values that decreasing the $\mathrm{pH}$ to a more normal value for grassland might be accompanied by a growth retardation in grasses and clover (Dijkshoorn et al., 1979).

Fig. 1 shows the relation between the contents of heavy metals at various depths in the soil after 5 annual sludge dressings at a rate of 18 tonnes of dry matter per

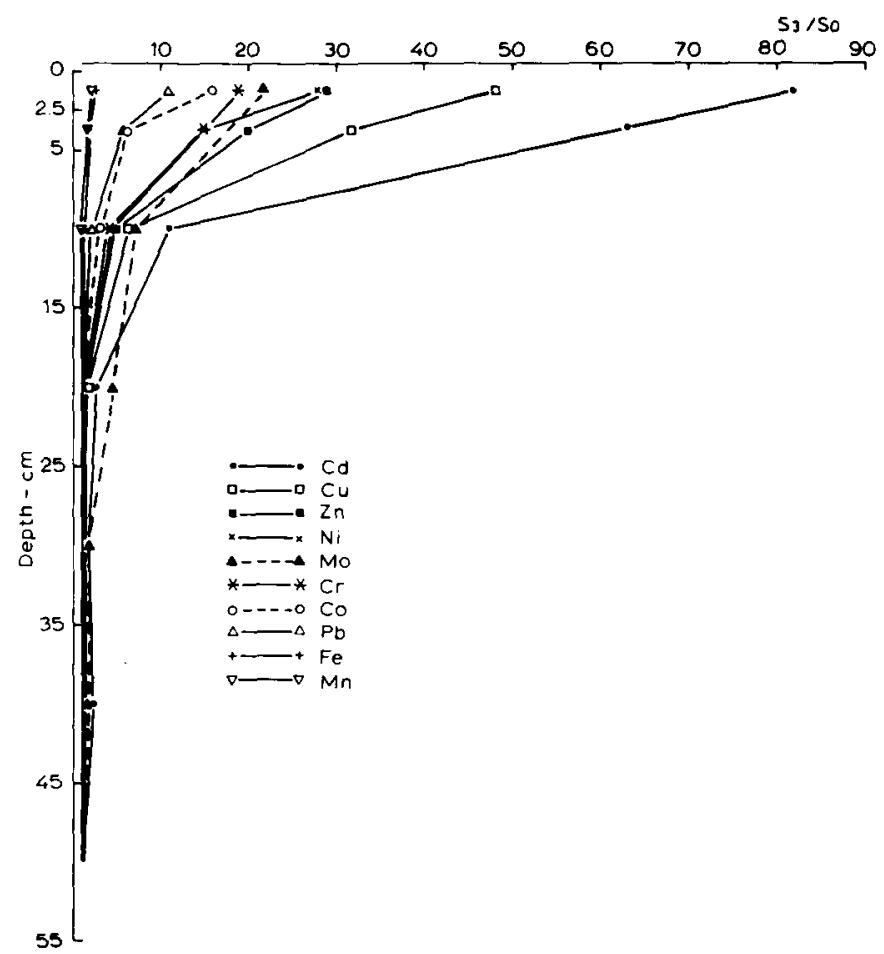

Fig. 1. Relation between the content of heavy metals in the treatment with the highest sludge dressing (S3) and the 0 treatment (SO) at various depths in the soil after 5 annual sludge dressings of 18 tonnes of dry matter per ha. 


\section{O. J. HEMKES, A. KEMP AND L. W. VAN BROEKHOVEN}

hectare per year and the 0 treatment $(\mathrm{S} 3 / \mathrm{S} 0)$. The great scatter in the $\mathrm{S} 3 / \mathrm{S} 0$ ratio of the various heavy metals in the top $2.5 \mathrm{~cm}$ layer of the soil is evidently due to the great differences in the supply of heavy metals with the sewage sludge with respect to their initial contents in this soil layer, before the sewage sludge dressings. It was to be expected that the scatter would remain great in the next $2.5 \mathrm{~cm}$ layer. It is striking that the S3/S0 values for most of the heavy metals discussed have already dropped to the lowest possible value $(=1)$ in the $15-25 \mathrm{~cm}$ layer. This indicates only a slight translocation of the metal ions from the top layer, which may have been caused by the $\mathrm{pH}$ value which increased under influence of the sewage sludge dressings. It is also in agreement with the findings of many other authors reporting decreased uptake of heavy metals by the crop and so a lower mobility of these metals with a neutral $\mathrm{pH}$ value than with a low $\mathrm{pH}$ value of the soil.

The contents of cadmium and copper show the sharpest rise in the top soil layer. Both metals have also penetrated to a greater extent to deeper layers of the soil profile. Whether the trend in the $\mathrm{Cd}$ curve at greater depth reflects the actual situation is not quite clear. It is in accordance with Harmsen (1977) who assumed on the basis of differences in the contents of heavy metals in the soil profile that the mobility of cadmium ions might be greater than those of zinc and lead.

Since for molybdenum and cobalt the trend in the S3/S0 values from the $2.5 \mathrm{~cm}$ soil layer to deeper layers could not be determined reliably, they are indicated by an interrupted line in the figure. However, apparently the contents of molybdenum have increased more sharply than those of the other metals between 15 and $45 \mathrm{~cm}$. This could mean greater mobility of the molybdenum ions in the top soil, brought about by the almost neutral $\mathrm{pH}$ value in this layer. The following argument may also indicate greater mobility. The actual increase in the contents of the heavy metals cadmium, lead, zinc, copper and molybdenum in the $0-5 \mathrm{~cm}$ soil layer of the S3 treatment was compared with the increase expected on the basis of their contents in the sewage sludge used. Proceeding from these contents and the initial contents in the soil, the metals were arranged according to the decrease in their increasing contents in the 0-5 cm layer: $\mathrm{Mo}, \mathrm{Cd}, \mathrm{Cu}, \mathrm{Zn}, \mathrm{Pb}$. However, the actual order was: $\mathrm{Cd}$, $\mathrm{Cu}, \mathrm{Mo}, \mathrm{Zn}, \mathrm{Pb}$. The increase in the Mo content in the $0-5 \mathrm{~cm}$ layer was lower than expected on the basis of the supply with the sludge. In view of the greater mobility of the molybdenum ions assumed before, probably more molybdenum than other metals penetrated to deeper layers. The trend in the Mo curve in Fig. 1 also reflects this to some extent. Moreover, more molybdenum was supplied with the sludge in a period of 5 years than could roughly be calculated on the basis of the increased Mo contents in the $0-55 \mathrm{~cm}$ layer of the soil profile. For the other heavy metals in the series the reverse was found. At the depth to which the soil was sampled ground water was present, which could imply that a part of the molybdenum supplied with the sewage sludge leached to the ground water.

\section{References}

Brouwer, J. W., 1977. De produktie en afvoer van afvalwaterzuiveringsslib in Nederland. $\mathrm{H}_{2} \mathrm{O} 10$ (1) 2-7. Dijkshoorn, W., L. W. van Broekhoven \& J. E. M. Lampe, 1979. Phytotoxicity of zinc, nickel, cadmi- 
um, lead, copper and chromium in three pasture plants species supplied with graduated amounts from the soil. Neth. J. agric, Sci. 27: 241-253.

Engers, L. E. van, 1980. Enquête betreffende de produktie, bestemming en kwaliteit van zuiveringsslib in Nederland in het jaar 1978. $\mathrm{H}_{2} \mathrm{O} 13$ (13) 293-294.

Field, A. C. \& D. Purvis, 1964. The intake of soil by the grazing sheep. Proc. Nutr. Soc. 23: XXIV.

Haan, S. de, 1976. Afvalwaterzuiveringsslib als meststof of grondverbeteringsmiddel. Landbouwk. Tijdschr./pt 88-1: 21-27.

Harmsen, K., 1977. Behaviour of heavy metals in soils. Thesis, Agricultural University, Wageningen.

Hofstee, J. en H. J. Fien, 1971. Analysemethoden voor grond, gewas, water en bodemvocht. Rijksdienst IJsselmeerpolders, Kampen.

Perrin, D. D., 1946. N.Z.Jl Sci. Technol., 27A: 396. 